\title{
DEVELOPING BATIK CIMAHI BY RE-DESIGNING COLOR AND BATIK MOTIF OF TRADITIONAL VILLAGE CIREUNDEU, CIMAHI, WEST JAVA, INDONESIA
}

\author{
Morinta Rosandini ${ }^{1 *}$, Rizky Noorrahmi ${ }^{2}$ \\ ${ }^{1}$ S.D.s, M.Ds. Mrs., Telkom University, INDONESIA, morintarosandini@tcis.telkomuniversity.ac.id \\ ${ }^{2}$ Ms., Telkom University, INDONESIA, ririznoorrahmi@gmail.com \\ ${ }^{*}$ Corresponding author
}

\begin{abstract}
Cimahi introducing its Batik trademark as the identity of the city on $8^{\text {th }}$ anniversary which took place on June $21^{\text {st }}, 2009$. Basically batik cimahi inspired by the cultural and nature resources that come from what is owned by Cimahi. One of the patterns that characterize batik Cimahi is Cireundeu pattern. The people of Kampung Adat Cireundeu have been known as the consumer of cassava and their Sunda Wiwitan beliefs as well. Until now, the development of cireundeu batik pattern just inspired by cassava only, while there are a lot of other ideas that can be used as a source of inspiration, especially as batik pattern and color inspiration.

In this study, the researcher conducted a study in the Kampung Adat Cireundeu to see the possibility of the potential in the cultural and natural resource belonging to Kampung Adat Cireundeu and to find the distinctive batik color scheme. From the development of the potential sources, obtained results in the form of batik stylized and composition inspired by Satu Sura, their annual ceremony, and by cassava which has become the staple food of the villagers.

The result obtained from this study is batik cimahi pattern's development inspired by Kampung Adat Cireundeu using batik tulis and stamp technique. The study is to make the cultural and natural potential that already exists in the Kampung Adat Cireundeu as a source of inspiration for Kampung Adat Cireundeu itself and to develop batik Cimahi as city identity as well.
\end{abstract}

Keywords: Batik, cimahi, motif, re-design.

\section{INTRODUCTION}

Cireundeu is a village in southern city of Cimahi, which name is derived from Reundeu plants. It used to grow at this village, in a very huge number. Another meaning of the origin name of word Reundeu, in Sunda language is 'living and working together'. It tells us that the philosophy of working hand-in-hand and help each other in everyday society of Cireundeu always conduct in their activities. The village is located at district of South Cimahi, Cimahi City,West Java, Indonesia. It is known as a 'traditional heritage village' by 
local government. There are 50 families or 800 people living there, most of them are cassava farmers and still retain their ancient beliefs.

"Ngindung Ka Waktu, Mibapa Ka Jaman" is principle beliefs of Indigenous people of traditional village in Cireundeu. In sunda language means the villagers have their own ways and characteristics of specific beliefs form their ancestors and still holding it until now, but in the other way they will not resist the changing of times, and still following the influence of technology such as, television, cell phone, and electricity.

Because of its unique characteristic of Cireundeu village and society, in December 2008 Cireundeu served as one of the Batik motif creation of local Batik, the Cimahi Batik. Along with the other unique symbols and regions of Cimahi, local government officially announced the Cimahi batik as local special identity, and Cireundeu has been named as one of its motif batik, the Cireundeu Motif Batik.

Unfortunately, the development of Cireundeu Batik is not growing significantly. The motif inspiration only limited with one shape and few numbers of combinations. Mostly it comes from the shape of the staple food of Cireundeu traditional village, which is the cassava leaves. While in the traditional village itself has a lot of natural and cultural potential that can be used as inspiration motif. Some of the shape that become their inspiration are houses, typical plant such as reundeu trees, and the most interesting is from their annual ceremony; the Satu Sura traditional ceremony. On the other hand, Cireundeu motif still do not have a particular character colors that represents a soul of Cireundeu, due at the beginning of its design was only focused on the shape of motif not the color.

This is exactly being the focused of the research to develop Cireundeu Batik, by re-designing motif and the color. It would be very unfortunate if of the many natural and cultural potential of traditional villages Cirendeu only create from limited shape. Therefore, it needs further exploration that elevates the traditional village Cirendeu as one of the part of Cimahi Batik, and then the Cireundeu elements of nature and culture could reinforce the identity of the Cimahi city. The other urgency for this research is to enhance the creativity of the local society; indirectly it also could increase the quality of life for the society.

\section{THEORITICAL BACKGROUND}

\subsection{Batik}

According to Sylvia Fraser (1986) in a book entitled Indonesia Batik Processes, Patterns and Places, she said that "Batik is the tick suffix means 'little dot', 'drop ' or ' point' but it can also denote a ticking or tapping sound. This root meaning may be seen also in words such as tritik, nitik and klitik ". According to its technique, Batik could explain as a technique to make motif on the surface by resist the color on the fabric using wax (Ramadan, 2013).

Garret Pieter Rouffaer, a researcher from the Netherlands who worked for Ethnograpicsch Rijks Museum in 1914, wrote the book "De Batik - kunst in Nederlandsch - Indie" and identified more than 1,500 variants Batik motif in the Indonesia. In October 2009, UNESCO designated Indonesian Batik as Cultural Heritage Humanity's Oral and non-material to be preserved.

\subsection{Cimahi's Batik}

Batik Cimahi was originally created as an effort to reinforce the city identity. The Batik Motif Competition held by the National Crafts Council (Dekranasda) part of local government of Cimahi city on December 19, 2008, in order to find artisan motif to make Cimahi Batik Motif. Batik is be lived as one of cultural heritage and also as a national asset that must be maintained and preserved, because the cultural heritage of a community containing intellectual property. Batik is also being lived one of the national cultural icon that has been known widely in foreign countries. (http://dekranasdajabar.org/21March/2016).

Dekranasda Cimahi city receives 89 batik designs and the participants are students, art galleries and culture, as well as the general public around the region of Cimahi and Cimahi. According to archive data Dekranasda Cimahi, assessment of Cimahi batik design competition conducted by the expertise judges: $\mathrm{H}$. Komarudin Kudiya SIP, M.Ds. (Batik expert and owner of Batik Komar), Ken Atik (Batik Expert, fashion designer and lecturer) and also Drs. Adang Kosasih, MM. (Vice Chairman of Dekranasda's Cimahi).

Based on the results of the judging, determined the winners as follows:

- 1st winner: Didi Sahadi from West Bandung district with woven bamboo design (Ciawitali.)

- 2nd winner: Muhammad Yaser from Cimahi, with lereng kujang motif design.

- 3rd winner: Dadang from Cimahi, with cassava leaf design (Cireundeu). 
- Favourite (people choice): Yudhi Halyanto from Bandung, with the design of bamboo trees.

Batik Cimahi continues developing the motif still refers to the five major themes from The Batik Motif Competition. Every batik craftsman in Cimahi, has distinctive features of each in terms of color, motif and materials. There are currently 3 well-known Cimahi batik makers, whose are Lembur Batik, Batik Anggraini, and Batik Sekar Putri.

\subsection{Cireundeu's Batik Motif}

Cirendeu motif created by Dadang (the 3rd winner of Batik Motif Competition) more representative of indigenous peoples Cirendeu village located in the area Leuwigajah, South Cimahi. Cassava has been a substitute for rice as the staple food for the local community for 80 years, has been the inspiration for Dada to create the motif. So, in this Cirendeu motif, cassava and cassava leaf motif dominates (Ramadan, 2013).

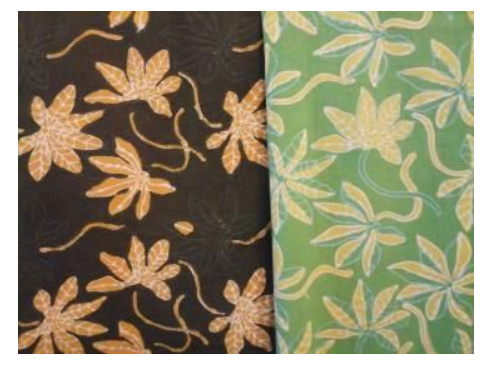

Fig 1. Cireundeu's Batik Motif

Source: Personal Documentation (Rizky,2016)

\subsection{Cireundeu Traditional Village}

Cireundeu indigenous villages are still holding its ancestors beliefs, it is known as Sunda Wiwitan. Sunda Wiwitan is not describing their worship but it means of the way that they applying the rules of life. The particular ceremony that they have applied to their life is the Satu Sura (Suraan) traditional ceremony.

Villagers annually routinely perform rituals Satu Sura as described by Rachmandika (2013) that:

"Islamic New Year coincided with the first of Muharram. ... According to Abah Emen, Chairman of Kampung Cireundeu, ritual 1 Sura were routinely held since the epoch, is one of the symbols of the philosophy. Suraan ceremony, thus Cireundeu residents call it, has a deep meaning. That man must understand when it coexist with other human beings. (Rachmandika, 2013: 7)

When the ceremony was held suraan, traditional village communities Cireundeu provide decorations in the village hall as a form of gratitude for nature gift for them. Gunungan: In the next stage, there is a gazebo decorated with a mound shape (resembling an triangle shape) which is formed of several steps. (http://budaya-indonesia.org/Filosofi-Dekorasi-Upacara-Suraan-Kampung-Adat-Cirendeu/21 March/ 2016).

1. Gunungan: On the pole on the stage there are some crops that are composed by a grow its fruit. In order from top to bottom, namely coconut, banana, corn, long beans, carrots, eggplant, radish, peanuts and cassava.

2. Leaves: In addition to food, there are some plant leaves are also used for decoration such as hanjuang $t$ and caringin tree. Those are their origin plants.

3. Janur: The leaves are used to make the leaf is taken directly from Cirendeu. The manufacturing is not only done by adults, but youth as well. Making the leaf is deliberately taught as early as possible so that the next generation quickly familiar with the culture.

4. Flag: The flag is associated in bamboo and installed along the village road, as well as associated in the ceiling of the stage, symbolizing the four elements of life. Red means fire, white means water, yellow means air, and black means land. None of them has special position; everything has meaning by adjoining each other. It showed that life should be balanced. 


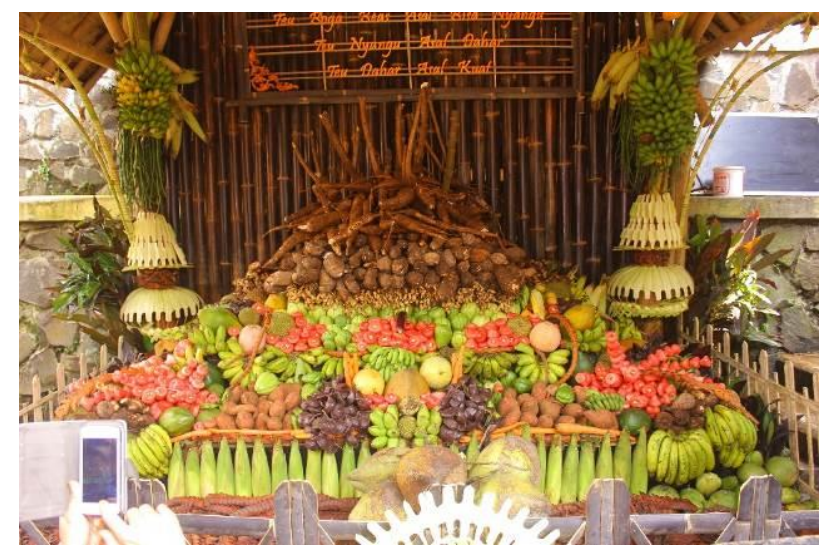

Fig 2. Gunungan Suraan

Source: budaya-indonesia.org (accessed on March, 21st 2016)

\section{THE RESEARCH METHOD}

The method used in this research is qualitative method and done as follows:

a. Study literature: Data collection by collecting literature; books, articles, and websites to find theories that strengthen the research.

b. Observation: Conducting a survey to Indigenous Village Cireundeu to Cireundeu Indigenous Village elders, and visiting some Cimahi batik craftsmen.

c. Interview

d. Conducting interviews for Indigenous Village elders Cireundeu, Cimahi batik artisans, and Dekranasda Cimahi.

e. Exploration: Conducting exploration and development in motif and color inspired by Indigenous Village Cireundeu.

\section{RESULT AND DISCUSSION}

\subsection{Image Board}

The theme of the development of Cimahi batik motif is "Batik Cireundeu's Story" which inspired motif taken from the Suraan traditional ceremony and the cassava tree. Suraan been selected for the Suraan tradition part of the indigenous villages Cireundeu public faith, the Sunda Wiwitan. And cassava was chosen because it's already become early inspiration on Cimahi batik motif Cireundeu. But this design inspired by the leaves, stems, and flowers of aged cassava.

The theme "Batik Cireundeu Story" shows in the image board represents the forms of traditional village communities of Cireundeu tradition that has been set in advance and then used as a design reference.

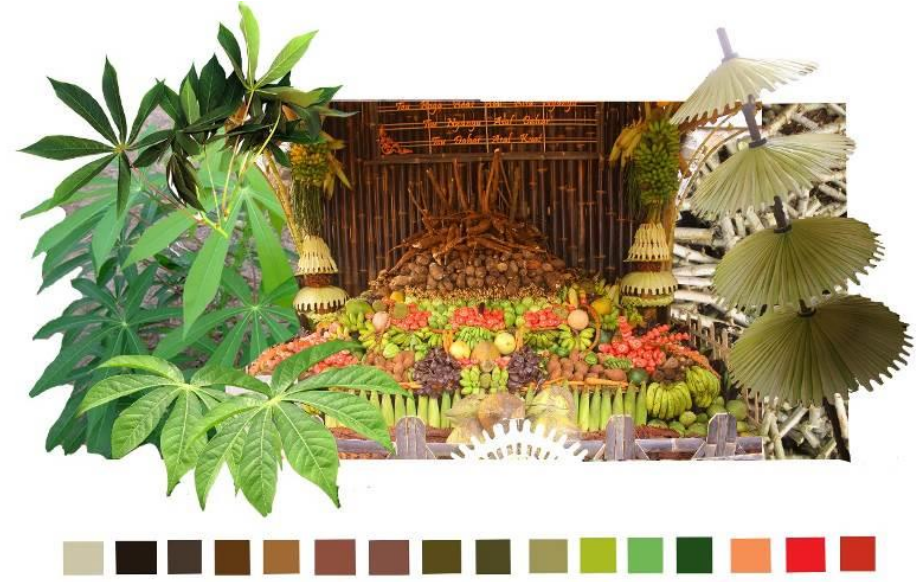

Fig 3. Image Board "Batik Cireundeu's Story" Source: Personal Documentation (Rizky,2016) 


\subsection{Motif Exploration}

Motif exploration is made by processing the natural elements of the smallest element in the traditional village Cireundeu. Processed forms such as: cassava species/genus, cassava leaves, cassava stems, elements ceremonial mound on one sura. Processing was done by using stylized motifs, namely by simplifying of original form, the following stylized process that has been carried out:

Table 1. Motif Exploration (Styling-forms)

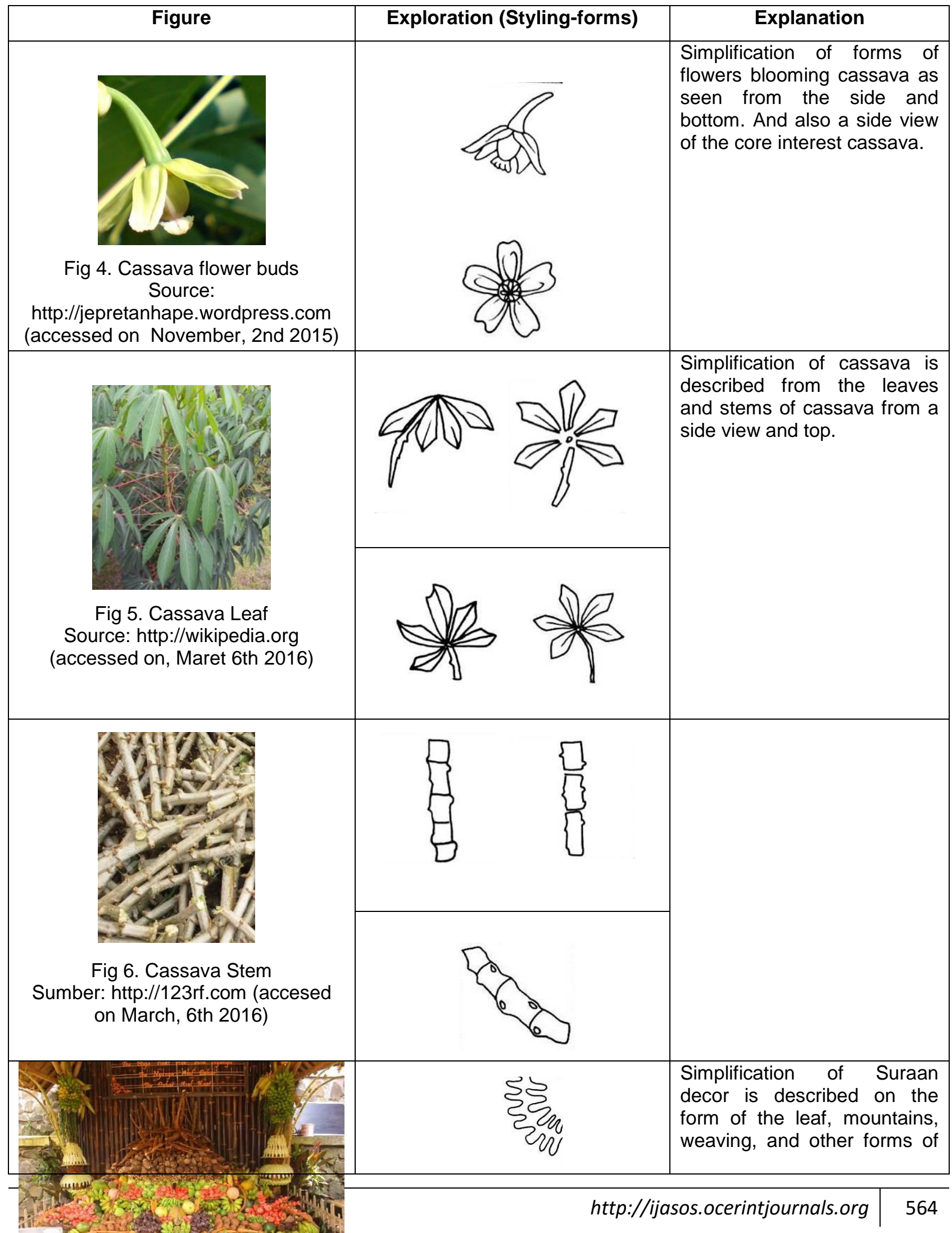




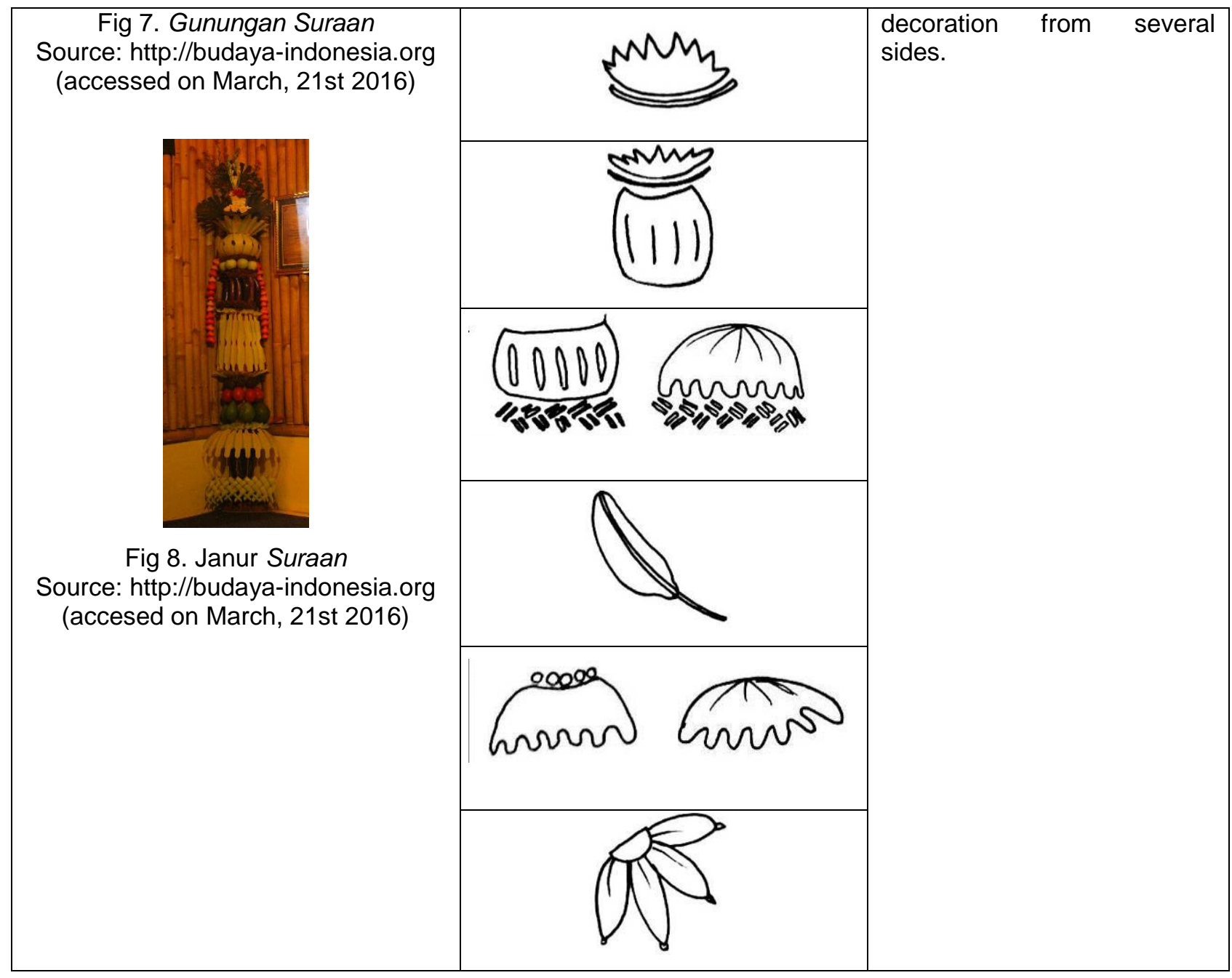

\subsection{Re-designing Motif}

Re-designed is done by applying the elements of Suraan decorations of traditional ceremony and also the shape of cassava. Those elements are re-created and arranged in a new composition, to make the harmony. The composition should consider the principal of visual basic, to produce harmonious composition motif. (Shaik, 2005: 6).

Tabel 2. Re-designing Motif

\begin{tabular}{|c|l|l|}
\hline Motif Composition & Elements & Technique \\
\hline & - Cassava Leaf & $\begin{array}{l}\text { - Make the curvaceous pattern } \\
\text { from those elements. }\end{array}$ \\
& - Cassava Stem & $\begin{array}{c}\text { Arrange it with dynamic row, } \\
\text { considering balance and } \\
\text { harmony. }\end{array}$ \\
\hline
\end{tabular}




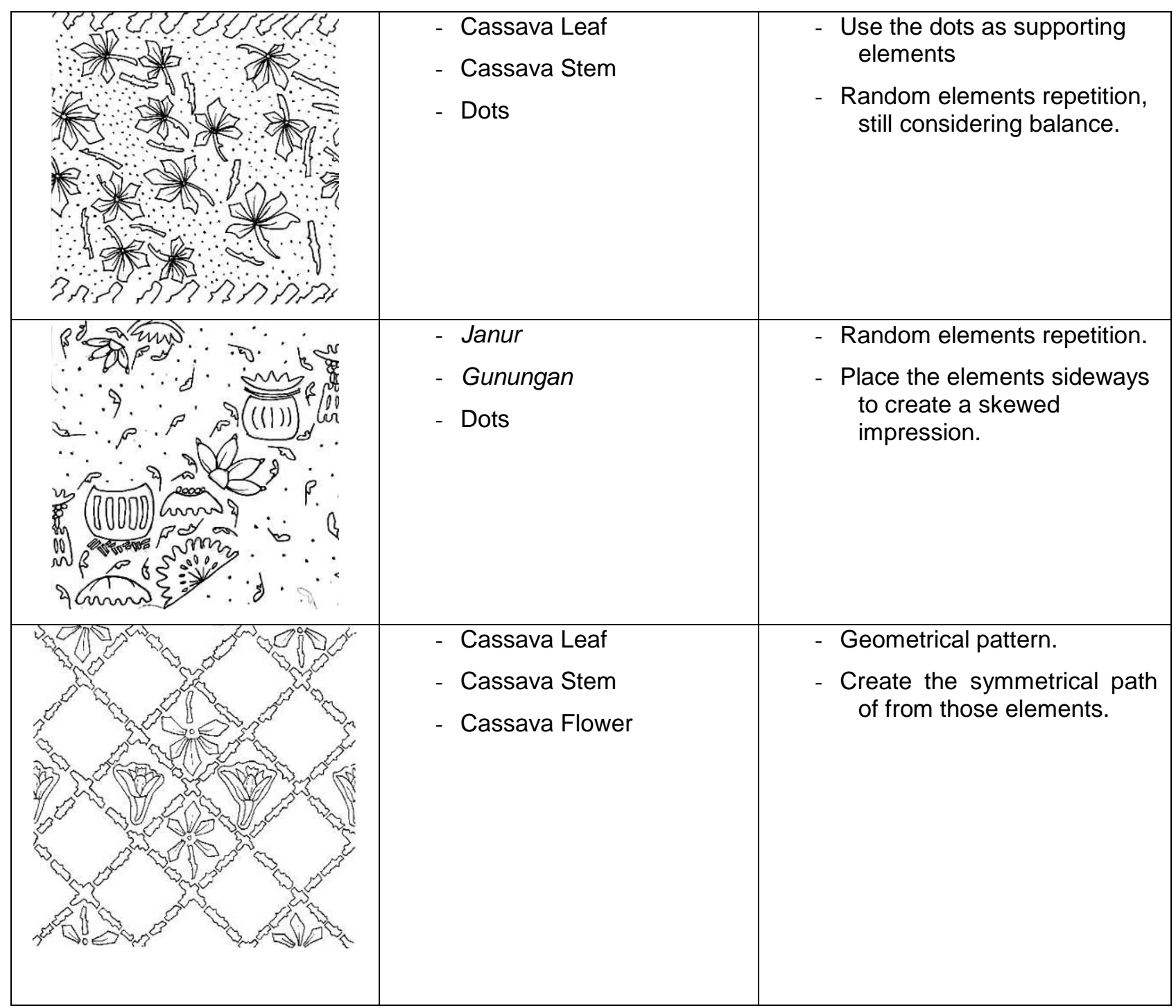

\subsection{Color Board Concept}
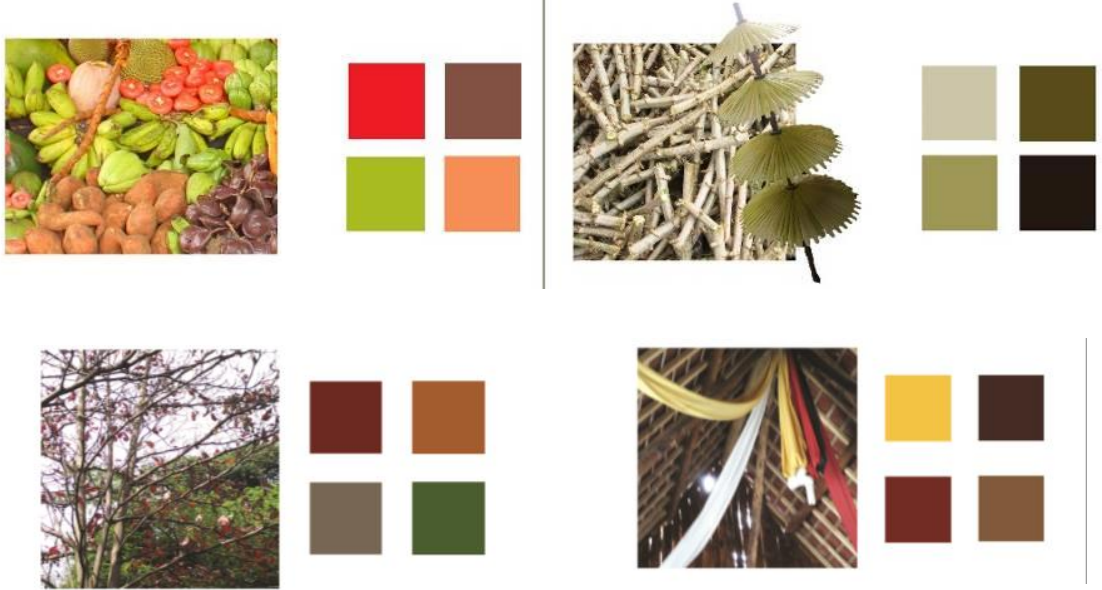

Fig 9. Color Board

Source: Personal Documentation (Rizky,2016) 
Another objective of this research is to create the characteristic color of Cireunde's Motif Batik. To developt the color it should well represent Cireundeu, source of inspiration is taken from the traditional village Cireundeu. After conducting observations and interviews to elders customary village in Cireundeu, it is finally defined the color board concept. Color board taken from the color of Gunungan Suraan (fruits, vegetables, and tubers), cassava stems, and the top peak of the Gunungan Suraan decorations. The color board are shown as follows:

Then the color concept is applied the Cireunde's Motif, as shown as follows:

Table 3. Color Application on Motif

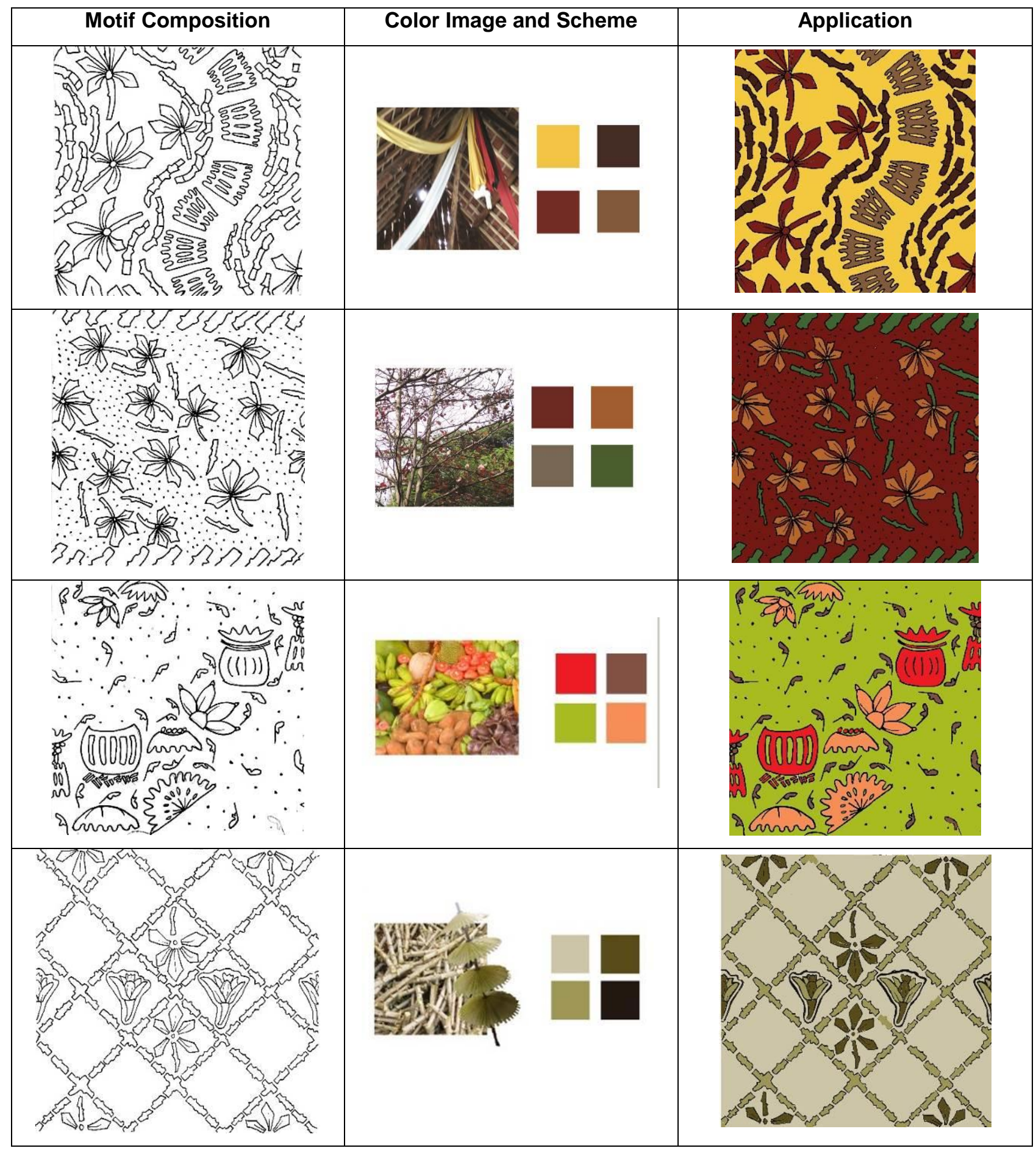




\subsection{Final Composition Color and Motif}

Final part in the developing the motif is done by the composition of the technical textiles chart; the techniques are one step and half-step technique. Motif repetition technique that we use is one-step technique. It's a continuous pattern which repeating the motif up-down, left-right in one-step. Whereas, the half-step technique is a composition motif when the motif repeats like a bricks structure, it is a half-step repeat up-down or left-right.

The purpose of this step is to show the overall motif in a larger size. Here above the final table composition of color and motif:

Table 4. Final Composition Color and Motif

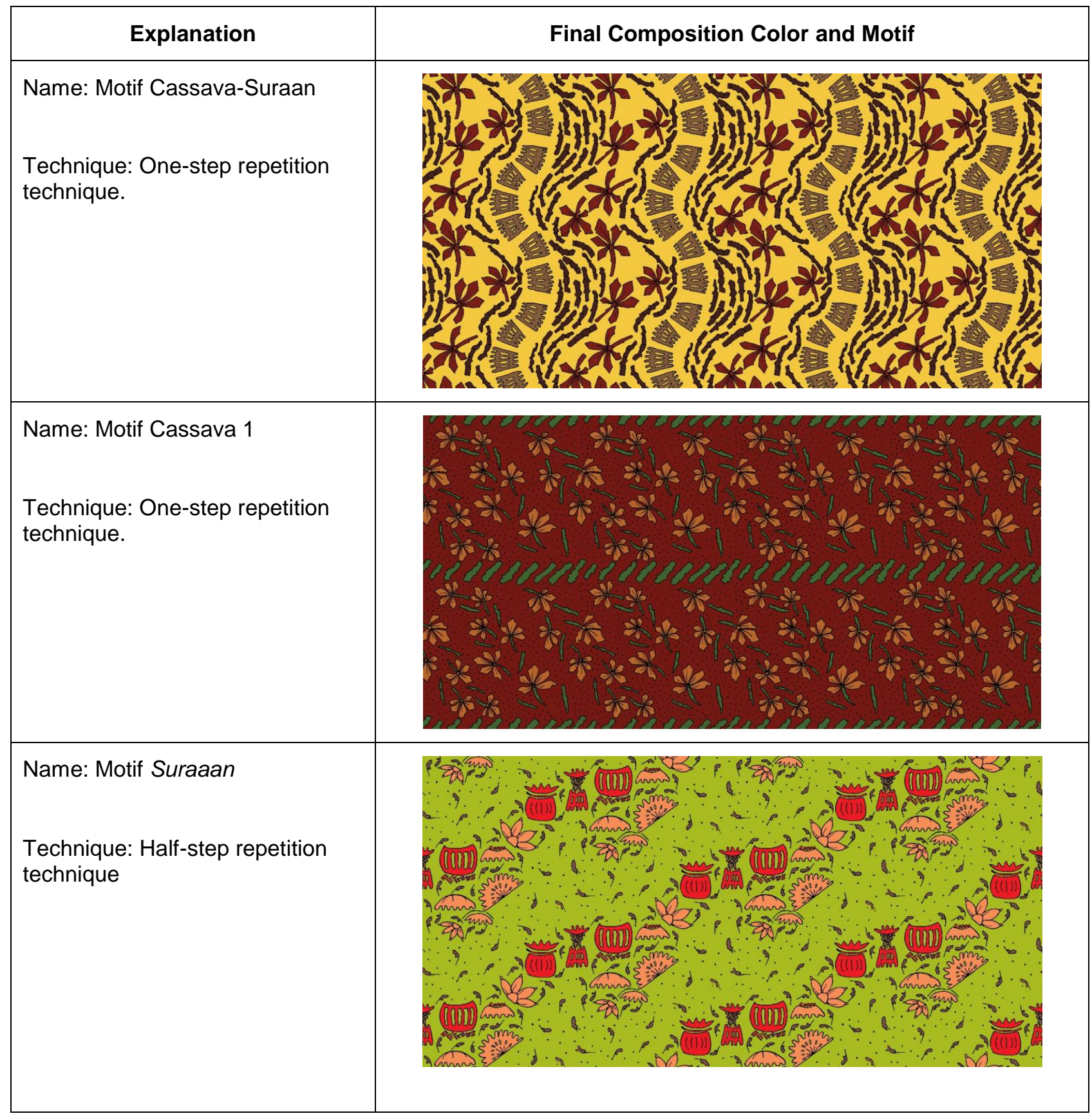




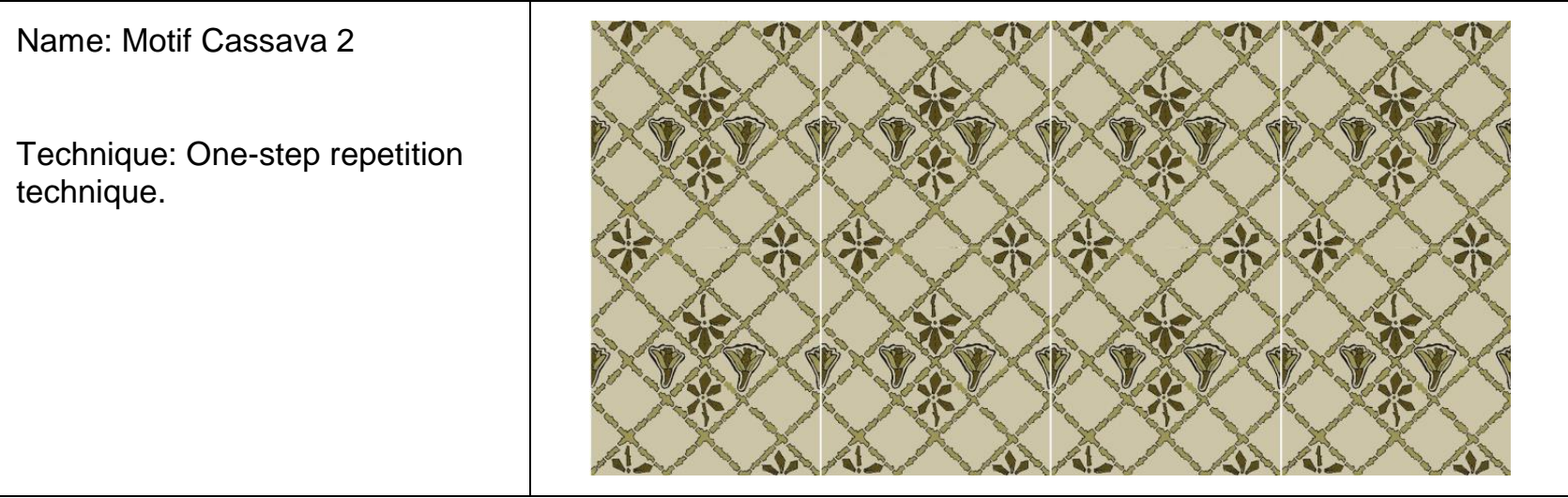

\subsection{Significance of Developing Motif Batik Cireundeu}

Many regions in Indonesia developed their own batik motif by its philosophy, based on characteristics that are owned by their regions. Cimahi was initially not batik development centers or areas that already have a tradition of batik at first, but Cimahi has potential from its natural and cultural elements to develop its batik tradition and motif batik creation. Cireundeu as one of Cimahi region has a lot of potential, from cassava leaves and elements of ceremonial tradition of Cireundeu society, satu sura. Those shapes could create character of motif batik Cireundeu the name of the motif is Cassava-Suraan motif.

Nowadays, Cireundeu as part of Cimahi still try to find its identity to become a city with strong character, so that people and tourists could recognize Cireundeu and would come to Cimahi. The significance of developing motif batik Cireundeu is to create the strong city identity, to enhance the creativity of people in Cireundeu, and to upgrade the life quality of the local society.

\section{CONCLUSION}

Cireundeu has many natural and cultural potential as inspiration motif. Inspiration forms that can be processed include cassava leave and cultural elements of the sura.

Re-designed motifs are done by processing and stylizing the smallest elements of the form (1) cassava leaf, (2) cassava stem, (3) suraan decoration of mountains suraan smallest element, namely coconut.

Apart from the motif, color processing for Batik Cireundeu also necessary because since the beginning their batik made has no specific color identity. The concept of color theme is determined from the color elements of nature that exist in Cireundeu: (1) The color of the mountains as an Cireundeu landscape, (2) Suraan decoration (fruits, vegetables, and tubers), (3) cassava stems and leaf of the decoration Suraan, and the last is (4) Cireundeu flag.

Those two chosen concepts; stylized shape and color concepts, created four main compositions of the redesigned batik motifs and colors of Cireundeu. Processing of these motifs can enrich culture and strengthen the identity of the city of Cimahi. Application of this motif can be done with batik technique, technique and technique canting cap

\section{REFERENCE LIST}

Fraser, Sylvia. (1986). Indonesia Batik Processes, Patterns and Places. Oxford University Press Iwet, Ramadhan (2013). Cerita Batk. Indonesia,Tangerang: Literati.

Rachmandhika, Aditya. 2013. Perancangan Film Dokumenter Kampung Cireundeu Final Project Report..UNIKOM Library.

Shaik, S. Shakeela, Begum, Sabina. (2005). Intermediate Vocational Course Second Year TRADITIONAL TEXTILES For the course of FGM \& CGD\&M.

http://budaya-indonesia.org/Filosofi-Dekorasi-Upacara-Suraan-Kampung-Adat-Cirendeu/21 March/ 2016 http://dekranasdajabar.org/21March/2016

http://kumkm-cimahi.page.tl/Batik-Cimahi.html/19 November/2015 